\title{
Accountability of State Islamic Religious College (SIRC) In South Sulawesi Indonesia
}

\author{
Muhammad Wahyuddin Abdullah ${ }^{1}$, Hadriana Hanafie ${ }^{2}$, Andi Yustika \\ Manrimawagau Bayan ${ }^{3}$
}

\author{
1,3 Alauddin State Islamic University of Makassar, Indonesia \\ ${ }^{2}$ Wira Bhakti Economic High School of Makassar, Indonesia
}

\begin{abstract}
The research aims to examine the influence of spirituality, organizational culture, leadership, and local wisdom on the accountability of State Islamic Religious College (SIRC). Sample research by 84 respondents in accordance with purposive sampling derived from 4 SIRC in South Sulawesi, that is UIN Alauddin, IAIN Palopo, STAIN Parepare, and STAIN Watampone. Research Data form of total score is obtained by distributing a list of structured questions to respondents. Respondents responded that spirituality, organizational culture, local wisdom, leadership, and accountability became an important part of SIRC's management in South Sulawesi. Hypothesis testing using multiple regresion. The results of the hypothesis testing showed that the local spirituality and wisdom positively affected the significant of SIRC's accountability in South Sulawesi. However, the organizational culture and leadership has no significant effect on the accountability of SIRC in South Sulawesi. The sublime values of worship increased accountability, but the symbols (norms) of organization and leadership characters did not make the accountability of SIRC in South Sulawesi.
\end{abstract}

Keywords-Accountability, Spirituality, Organizational Culture, Leadership, Local Wisdom.

\section{INTRODUCTION}

The college or University as a social institution in charge of developing science and technology is one of the institutions that feel the most social demands for quality improvement. Education accountability is a manifestation of the educational institution's duties to account for the success or failure of the implementation of the education process (Sutjiati, 2008). Amid intense competition, quality improvement is inevitable in order to compete for community confidence and sustainable existence.

Accountability of educational institutions, especially universities, seems to have increased public demand with the establishment of Good University Governance (GUG) to improve the sustainable quality of universities. Accountability is intended to explain what has been done, then interpreted as an obligation to account for or explain the performance, look from success and unsuccess in carry out its mission. The performance is not only measured by the potency of the State Islamic Religious College (SIRC) to score the intelligent generations of cognitive but also able to make colleges a center of civilization.

SIRC as a high institution based on spiritual and Islamic values is supposed to present the management of university that is appropriate to the values of Islam. These values are manifested in the accountability practice as described in the QS. Al-Anfal: $8 / 27$ requiring the trustee to guard the mandate given and should not be traitorous. The verse describes human responsibility not only to the person who gives the trust but the most important of all is human accountable to Allah SWT and his apostle.

Research of Rafaeli and Worline (1999) links the symbols and values underlying the organization. The study states that the symbol serves four functions in the organization, which is integrating feelings, thoughts, and actions into meaning code. Islamic values contained in the symbol and identity of college based Islamic religious should be attached to the organization that is internalized in the individual in behavior. The values and principles embraced 
by a person will greatly determine the pattern of his behavior. The internalization of symbols and values that identity an organization into each individual will make it easy to achieve the vision and mission of the organization, as all elements involved in the organization are focused on achieving common goals.

Research of Endahwati (2014) found that the accountability of Zakat, Infak, and Charity (ZIC) at Amil Zakat Management (AZM) of Lumajang is divided in two, vertical and horizontal accountability. The principle that emphasized of vertical accountability is the principle of trust, while horizontal accountability principles emphasize professional and transparent principles. The ZIC management accountability practice undertaken by AZM Lumajang is a synergy of spiritual accountability, service accountability, accountability programs, and accountability reports. The aspect of spiritual accountability has the meaning that individuals or organisations have the awareness of claim accountability to the transcendent (God).

Spiritual Accountability exbued every individual to act in the passion of spiritual values believed and realizeed in the behavior of each individual as a member as well as the leader of the organization. The reflection above shows that the practice of accountability does not only run the rituals but also touch the conscience of each individual, which appears to surface as a result of the contemplation process. Accountability involves deep conscience every individual or organization upholding the values of honesty and ethics that become a universal nod to be fought and realized in every individual activity (organization).

The insistence on stakeholders with the importance of implementing accountability by living the principles of good governance which includes transparency and the sense of fairness of each organization is a phenomenon that must be observed by every organization, especially the public sector so that the organization is trusted. Randa (2013) explained that to build the trust, the organization of the public sector should be able to understand the environment and culture of the society in which the organization resides. This is the underlying research that as a public organization, the management of SIRC must match the values believed by the community, because the community is a stakeholders respected their belief.

According to Effendi (2003) that the University world does not have a strong moral power to become a role model of society, because the transformation to civil society has not demonstrated the campus society develop itself into the ideal models of civil society, respecting the supremacy of law, democratic, civilisation, fair and responsible. The factor is institutional educational orientation is too material oriented, and the curriculum too emphasizes the ability of measurable cognitive aspects, and market oriented. People looking at religious-based colleges have more value than other colleges because it integrates moral and spiritual values. This is accomplished if all academic civitas understanding values of organizing organization and management of university.

The law Number 20 of 2003 on national education, states that university have the autonomy to manage their own institutions based on the principles of autonomy, accountability, quality assurance, and evaluation of transparency. The creation of accountability indicates moral values are integrated in the management of university. The management of State Islamic Religious Colleges is based with the values of Islam. The Islamic value spirit of university's management will internalize the people involved in their managing, which implicates to behaviour, actions, performance and performance.

The Spirit of accountability contains values that include universal concepts that cultivated in organizations such as truth, honesty, immorality, and others so that actions or decisions are made to reflect performance and can be accounted. This Spirit is not only manifested in the spiritual dimension, organizational culture, and local wisdom but must be born through leadership. Good leadership encourages management to walk as expected because everyone is encouraged to perform deeds for the common good.

Organizational accountability is not only understood as the obligation of agent of trust to give accountability, present, report, and disclosure all activities that are responsible to the trustee (Principal). Accountability of reflection meanings and values contained within the identity begins to be lifted from the core values of the philosophical organization or the values inherent in the symbol and identity inherent to the organization.

\section{OBJECTIVES}

Based on this, the purpose of this research is: 1) to know the influence of spirituality on SIRC's accountability; 2) to know the influence of organizational culture on SIRC's accountability; 3) to determine the influence of local wisdom 
on SIRC's accountability; 4) to know the influence of leadership on SIRC's accountability.

\section{THEORETICAL REVIEW}

\subsection{Shariah Enterprise Theory (SET)}

Shariah Enterprise Theory (SET) is developed based on zakat metaphors containing balanced character and has broader accountability scope than Entity Theory. The accountability meaning is accountability to God, human, and nature (Triyuwono, 2006:354). This form of accountability will create a consciousness of its users because accountability is doing as a form of high responsibility to God as Khalifatullah fil Ardh.

God is the highest customer and the only purpose of human life. The accountability of the company or the agency to God is a liaison rope so that the management and activities undertaken are based on the purpose of "raising the Divine Consciousness". This theory telling that every human activity of his primary accountability is to God. Mulawarman (2011) in Arga (2014) Confirm that if the SET has substance double entry, then the dimension of Accountability Khalifahtullah fil Ardh also have a partner, namely the dimension as 'Abd Allah SWT (submission and obedience to Allah swt). This human submission, according to Mulawarman (2007), is expected to affect the fulfillment of Maqasid ash-Sharia (Islamic goals), namely Mashlahah for people, social, and nature.

The second Stakeholder of SET is the human being by Triyuwono (2011) differentiated into two namely directstakeholders (parties who directly contribute to the company and its related agencies both in financial and non-financial form) and indirect-stakeholders (parties who do not contribute to the agency, especially the society and the environment in the sense of preserving, repairing and preserving nature). The last Stakeholder SET is nature. Nature contributes greatly to the sustainability of the company's life but nature does not require the form of welfare distribution and feed back from the agencies in the form of material as human wants.

\subsection{Accountability}

Accountability is an important pattern for public organizations. According to Sadjarto (2000) The accountability pattern is built for the improvement of performance benchmarks in providing public services, enhancing the process of managerial accountability and is an effort to control management of the organization. Roberts and Scapens (1985) said that accountability is a relationship that encompasses the granting and acceptance of something that is reasonably acceptable. Gray et al. (2006) and Gray (2001) said that accountability not only belong to individuals or organisations but property of the general public. Accountability is not limited to accountability for something that is handed over between two parties, but also about the moral aspects that are always championed in an organization and involve society.

The context of university, accountability by Campbell \& Rozsnyai (2002) is defined as the assurance of a unit to its stakeholders that they have provided a good quality education. Education accountability is a manifestation of the obligation of an educational institution to account for the success or failure of the implementation of the education process. The context of learning, should always be sought to be repaired and upgraded so that the learning process is optimal and effective, and can improve the quality of graduates.

University as public organizations must implement public accountability. Public accountability is the recipient's obligation to manage resources, report, and disclose all activities and activities relating to use of public resources to the principal. Accountability followed by the provision of capacity and authority. Public accountability consists of vertical accountability and horizontal accountability. According to Mardiasmo (2005:5) Vertical accountability is an accountability to the higher authority, while horizontal accountability is a broad accountability or to other organizatios that do not have a subordinate superiors.

\subsection{Relationship Spirituality with accountability}

Spiritual has many definitions and aspects that have been developed in various literature. Field (2007) in Efferin (2015) states that spirituality in the business is inseparable from the process of eliminating greed, alleviating suffering, developing compassion and wisdom on all living creatures and the environment. Milliman et al. (2003) explains that spirituality in the workplace involves efforts to discover one's destiny in life, developing a strong relationship between work related to work, and having consistency between one's core beliefs and organizational values.

Accountability to God relates to the nature of trust. It is no other as a manifestation of human function as Khalifatullah fill Ardh. According to Elfianto (2013), the dimension of accountability, especially in conventional 
accounting, as agency theory is the reduction of the concept of trustees into smaller dimensions where Islam sees everything that is deposited to human as Khalifatullah fil Ardh is the mandate. Endahwati (2014) states spiritual accountability reflects the professional value and transparency value. Professional value is visible in the personality of employees who have a consistent, confident, and not easy to give up in the conduct of the ZIC management tasks that are the mandate of Allah SWT.

Fikri, et al (2010) Finds that reporting accountability is not something important and most demanded by society. Society is more concerned with accountability of action, which is how organizations manage and empower them. Society assumes behavior or action is a mirror of the accountability itself. Studies of the spiritual accountability of the Protestant church were conducted by Saerang (2003) examining the Church of Pentecost in Indonesia and Randa (2011) who searching the Catholic Church organization in the land of Toraja. Saerang's research finds the accountability of the Pentacosta church varies from communal to bonded. Randa (2011) finds a dimension of the spiritual accountability of the church organization that exbued every individual to act in the passion of spiritual values believed and manifested in the behaviour of each individual as a member as well as the leader of the organization. Furthermore, Randa states the use of church organizational accountability practices differentiated in three main dimensions, namely spiritual, leadership, and financial accountability.

\subsection{Organizational cultural relations with accountability}

Gibson et al. (2012) state the organizational culture is a value system with together believe resulting in norms, behaviors, values (what is important), and beliefs (how it works) integrate lead to the norm as a guiding act. Kurniawan (2013) suggests that the culture of the organization give characteristics or traits that distinguish an organization from other organisations, where the patterns and values embraced as one of the guidelines by the entire member carry out their responsibilities and can influence the way members behave, how to describe work and how to work with other members. Kotter and Hesket (1997) in Triyono (2012) say that the organizational culture has two distinct levels seen from the side of their clarity and resilience to change.

Shahzad et al (2012) research shows that organizational culture has a profound impact on various organizational processes, employees, and their performance. The implementation of organizational culture is very helpful for employees doing their work effectively and efficiently. Religious colleges certainly have inherent values of everyday behavior and action. The value of the symbol can be internalized in the process a person receives and renders himself with a variety of attitudes, how to express feelings or emotions, fulfillment of desires, desires, passions, beliefs, norms, and values that individuals possess in their communities. Accountability is built by creating an organizational culture that encourages anyone to be accountable. Every academic civitas should be encouraged to carry out responsibilities according to the position held, so that the organizational culture is strengthened to familiarize the accountability.

\subsection{Local Wisdom relations with accountability}

According to Sartini (2004) Local wisdom is local ideas that are wise, full of wisdom, good value, embedded and followed by community members. Local wisdom shows the identity of an area that is formed as a cultural advantage of local people as well as geographical condition and become a tradition that is believed to be true. Every local culture of the region there is a sublime value that has actually been practiced in the past in the management and leadership of local community organizations before being touched by outside culture (Randa, 2015). These cultural values in the results of anthropology studies have a tremendous strength in creating accountability for governance and leadership of the community organization.

The research of Randa (2015) states the values of local cultures absorbed in the Catholic Church organization so that the organization of the Catholic Church develops into a Catholic church that cultures in the religious aspects and governance of more transparent, contextual, and accountable organizations. Accountability research on religious nonbusiness organisations (NGO) has been conducted by Randa et al. (2011 and 2013); Anzar and Januarsi (2011); Ningsih (2015). Randa et al. (2013) For example who researched about the dimension of accountability of local government organizations in Toraja, found a simple understanding of accountability by the Community, namely the accountability of output based on the dimensions of facility and infrastructure, education and health services, or its dominant indicators of facility and infrastructure.

Research on local wisdom based accountability like doing by Randa (2011 and 2015); Salle and Paranoan (2015) 
become indicate that accountability needs to be built on the foundation of local wisdom values believed by local communities. Randa (2015) finds the local values of South Sulawesi Indonesia which was lifted from the concept of the value of Siri'na Pesse and misa kada dipatuo pantan kada dipomate to give the significance of accountability built in an organization as a whole, so it can be received by all stakeholders. Salle and Paranoan (2015) Examine the manuntingi accountability of the Ammatoa (Kajang) society, giving the meaning of manuntungi accountability, which is upholding kalambusang (honesty), and fulfilling the other three elements, namely Gattang (firmness), Sa'bara ' (patience), and Nappiso'na (Tawakkal).

3.6 Leadership relationships with accountability

Leadership is the process of influencing or exempting leaders by their followers in an effort to achieve organizational objectives (Wikipedia, 2015). Leadership explores how senior leaders adhere to and use organizational values, hints and varying expectations/performance expectations; Focus on students, and stakeholders, students and organisational learning, empowerment and innovation, and in addressing various public/community responsibilities (Sutjiati, 2008). The leadership is one of the employers ' efforts to encourage all academic civitas to consistently run accountability practices.

Moral is the foundation of character building, knowledge mastery, environmental recognition, and social and global relationships. Moral aspects are universal in leadership. An organization or community motivates the highest morality for emitting an accountability of the conduct of a leader (Nugroho, 2013). The relationship of morality and accountability of leadership is complex influenced by culture factors, situations, and conditions. But indeed the relationship is simplified as a linear relationship. The necessary leadership is visionary and able to communicate well in working relationship with tutors, supporting personnel, and the citizen learning is needed conducive communication (Ramatni, 2013). Nurhayati (2014) explains the accountability of imposing some demands on officials, agents as servants of government or public service organizations, including university.

Leadership is one of the key factors of organizational life, including the public sector. Leadership issues make leaders always focused on evaluating the cause of the organization's success or failure. Gibson et al. (2012) defines leadership as the ability to influence a group of people to jointly achieve the goal. Leadership is 'formal leadership' in the sense that a leader is a person appointed and confirmed to occupy a particular position. Hudges (1992) in Pusparini (2010) say that "government organization are created by the public, for the public, and need to be accountable to it". Public organizations are made public, publicly, and therefore must be accountable to the public. Accountability is important as a form of accountability for position, leadership, and social responsibility.

\subsection{Past research}

Sutjiati Research (2008) on accountability as an effort to improve the quality of education. The research shows that the accountability of educational institutions needs to be done by all stakeholders from the government, general public, leaders, and workers of educational institutions, lecturers, students, parents, and others. All parties have a role in the educational world so this is as one of form feedback to all stakeholders. Shahzad et al. (2012) Research on organizational culture and its impact on organizational performance, showing that organizational culture has a profound impact on the various organizational processes, employees, and performance. It is also revealed that each individual will allow himself internalized by the values and beliefs adopted by the organization. Culture and spirituality play a role in triggering overall organizational performance.

Randa (2011) on the organizational accountability of the Catholic Church, which is a local cultural value. The study concluded that the meaning of accountability of the church organization was based on three dimensions, namely spiritual accountability, leadership accountability, and financial accountability. Spiritual accountability is done with the form of religious activities, leadership accountability is done to promote the element of service. Accountability Research in the frames of local wisdom is also performed by Salle and Paranoan (2015). The research gives the use of manuntungi accountability that is understood by indigenous Ammatoa (Kajang) as a reflection of daily behavior. The research with a qualitative approach is able to demonstrate that accountability is closely related to local wisdom.

\subsection{Research hypothesis}

Based on theoretical studies above with the context of SIRC based on Islamic values which consider the system of adopted values as well as norms that are carried out in a better understanding of institutional management, especially 
accountability practices. The concept is incorporated in the form of variables such as spirituality, organizational culture, local wisdom, and leadership. These four variables are internal and external factors affecting accountability. This research aims to determine the internalization of these four variables in SIRC, and then what the four variables are know by the SIRC's academic stakeholders. Thus, the research hypothesis was developed as follows:

H1: Spirituality affects the management of SIRC's accountability.

H2: Organizational culture affects SIRC's accountability management.

H3: Local wisdom influences the management of SIRC's accountability.

H4: Leadership affects SIRC's accountability management.

\section{RESEARCH METHODOLOGY}

4.1 Population and sample determination

The population of this research is a lecturer and structural officer at SIRC in South Sulawesi, Indonesia. Lecturers who have structural positions practise the accountability of the management of duties or trustees, both as functional officers and structural officials. In addition, they are required by regulations obliged to conduct good college governance accountability. SIRC is located in the South Sulawesi region including Alauddin State Ismic University of Makassarr, Islmic Institution of Palopo, State Islamic Institution of Bone, and State Islamic Institution of Parepare. The sample selection is done with a nonprobability (not random) using the purposive sampling method. The sample criteria meaning in this study are: 1) maintainers of majors (courses); 2) The managed study program has been accredited; 3) Manager of units or parts; 4) long manage courses or units (sections) at least 2 years.

\subsection{Types, Resources, and Data collection}

The type of data used in this research is subject data (self-report data) that is the attitude, experience, or characteristics of a person who is the subject of research/respondent (Indriantoro and Supomo, 1999:145). The data source uses primary data. Primary Data is obtained directly from the original source using a structured question list for the purpose of collecting information that matches the respondent's characteristics. Data collection using survey method, which is data obtained by distributing questionnaires

ISSN: 2456-7620

https://dx.doi.org/10.22161/ijels.53.33 to respondents directly and or through a network of person links.

\subsection{Analytical techniques}

For the overall testing of the hypothesis, this study used multiple regresion regression analysis. The regression equation Model for 1, 2, 3, and 4 hypothesis testing is demonstrated as follows:

$Y=a+\beta_{1 \times 1}+\beta_{2 \times 2}+\beta_{3 \times 3}+\beta_{4 \times 4}+e$

Description:

$\begin{array}{ll}\mathrm{a} & : \text { Constant } \\ \mathrm{X}_{2} & : \text { Organizational culture } \\ \beta_{1,2,3,4} & : \text { Regression coefficient } \\ \mathrm{X}_{3} & : \text { Local wisdom } \\ \mathrm{Y} & : \text { Accountability } \\ \mathrm{X}_{4} & : \text { Leadership } \\ \mathrm{X}_{1} & : \text { Spirituality } \\ \mathrm{e} & : \text { Error }\end{array}$

As for the Creatteria testing results of the model and the testing of each hypothesis as follows:

a. $\quad$ Calculated $\mathrm{F}$ value $\geq$ table $\mathrm{F}$ value or probability $\leq \alpha$ $(5 \%)$ so that, $\mathrm{Ha}$ is accepted (significant), and the opposite condition refuses $\mathrm{Ha}$.

b. $\quad$ Calculated $t$ value $\geq \mathrm{t}$ table or probability $\leq \alpha(5 \%)$ so that, $\mathrm{Ha}$ is accepted (significant), and the opposite condition refuses Ha.

\subsection{Operational Definitions}

- Accountability

The accountability of university according to Campbell and Rozsnyai (2002) is the assurance of a unit to its stakeholders that they provide quality education. Accountability is measured by referring by the one Book of Academic manuscript of the TIRE study Program accreditation-PT 2008 and Muawanah Research (2010), which includes leadership (managerial), human resources, and spiritual accountability, using Likert scale strongly disagree (1) until very concur (5).

- $\quad$ Spirituality

Spirituality is the fulfillment of inner life of meaning and purpose of the work done. Spiritual is not merely a ritual worship but past the boundaries of religious institutions so that it is able to be accepted globally. Spiritual value is measured by the availability of worship facilities and 
infrastructure, spiritual to God, and spiritual fellow like the Research Muawanah (2010), using Likert scale strongly disagree (1) until strongly agreed (5)

- Organizational culture

Organizational culture shows certain traits, characteristics, or properties that differentiate an organization with other organisations that contain the values and norms that become operational guidelines. The organizational culture is measured in terms of Schwartz's theory of value, which includes tradition, conformity, and achievement, using Likert scale strongly disagreed (1) until strongly agreed (5).

- Local Wisdom

The local culture of an area has sublime values that are actually practiced in the past by society in the management and leadership of local organizations before outside cultural touched (Randa, 2015). Local wisdom is measured by the value of the Sipakatau', Sipakainge', and Sipakalebbi' management and accountability practices of SIRC. This variables use Likert scale strongly disagree (1) until very concur (5).

- $\quad$ Leadership
Leadership involves the all of member and the personhood of the leader who is wise and dare to take decisions (Randa, 2011). Leaders become one of the determining indicators of achieving organizational objectives. Leadership is measured by visionary, response capacity, alertness, intelligent, and leadership capacity, with the use of Likert scale strongly disagree (1) to Very concur (5).

\section{RESULT AND DISCUSSION}

\subsection{Description of respondents}

Samples by 84th people are grouped based on the origin of SIRC respondents shown 1st table. The table explains that most of the research samples are predominantly based on Alauddin State Islamic University by 47 respondents $(56.0 \%)$, the next rank is derived from Islamic Institution of Palopo by 18 people (21.4\%), the respondents came from State Islamic Institution of Parepare by 10 people $(11.0 \%)$, and respondents derived from State Islamic Institution of Watampone by 9 people (10.7\%).

Table.1: Original composition of SIRC

\begin{tabular}{clcr}
\hline No & \multicolumn{1}{c}{ SIRC } & Total & Persentase (\%) \\
\hline \hline 1. & Alauddin SIU of Makassar & 47 & 56.0 \\
2. & II (Islamic Institution) Palopo & 18 & 21.4 \\
3. & SII (State Islamic Institution) Parepare & 10 & 11.9 \\
4. & SII (State Islamic Institution) Watampone & 9 & 10.7 \\
\hline & Total & 84 & 100.0 \\
\hline
\end{tabular}

Source: Processed primary data, 2016

\subsection{Variables description}

The spirituality variable shows the average number of 42.49 and the middle (median) point of 24.50 (3.5 x 7). The spirituality variable's average value is greater than its middle point value, which is $42.49>24.50$. The average value of a spirituality variable of 42.49 is closer to the maximum point value of 49.00 compared to a minimum point value of 28.00. Respondents responded to the aspect of spirituality in SIRC becoming an important part of college management.

The organizational culture variable shows an average rate of 38.61 and a middle (median) point of 24.50
( $3.5 \times 7)$. The organizational culture variable's average value is greater than its central point value, which is $38.61>24.50$. Organizational culture variable average value of 38.61 is closer to the maximum point value of 49.00 compared to the minimum point value of 19.00. Respondents responded to organizational culture into an important part that was built to manage the SIRC.

The leadership variable shows the average number of 39.93 and the middle (median) point of 24.50 (3.5 x 7). The average value of the leadership variable is greater than its middle point value, which is $39.93>24.50$. The average value of a leadership variable of 39.93 is closer to the

ISSN: 2456-7620 
maximum point value of 49.00 compared to the minimum point value of 23.00. Respondents responded to leadership as an important part needed to manage the SIRC.

The local wisdom variable indicates an average rate of 51.38 and a middle (median) point of 31.50 (3.5 x 9). The average value of the local wisdom variable is greater than its middle point value, which is $51.38>31.50$. The average value of the local wisdom variable of 51.38 is closer to the maximum point value of 63.00 compared to the minimum point value of 30.00 . Respondents responded to local wisdom implemented well in the management of SIRC.

The accountability variable shows an average rate of 55.54 and a middle (median) point of 35.00 (3.5 x 10). The average accountability variable rate is greater than its middle point value, which is $55.54>35.00$. The accountability variable average value of 55.54 is closer to the maximum point value of 70.00 compared to the minimum point value of 27.00. Respondents responded to the crucial accountability implemented in the management of SIRC.
The entire variable shows the average value of the 38.61 to 55.54 range greater than the standard deviation value of 4.93 to 10.03 . Comparison of average values with standard deviation for spirituality variables $42.49>4.93$, organizational culture $38.61>6.59$, leadership $39.93>7.29$, local wisdom $51.38>8.56$, and accountability $55.54>10.03$. All of these variables have a large variation or the lack of a response rate that is sufficiently large than the lowest (very disagreeable/very unimportant) with value its highest value (very concur/very important). The standard and average deviation values of each variable show a positive sign. It indicates that despite the large gap between the highest value and the lowest value, the gap is still in the same direction (positive), so it does not cause any symptoms of serious gaps or variations. The variable descriptions show in the following table.

Tabel.2: Variables Description

\begin{tabular}{llcccr}
\hline \multicolumn{1}{c}{ Variables } & N & Minimum & Maximum & Avarage & $\begin{array}{c}\text { Standard of } \\
\text { Deviation }\end{array}$ \\
\hline Spirituality & 84 & 28.00 & 49.00 & 42.4881 & 4.92717 \\
Organizational Culture & 84 & 19.00 & 49.00 & 38.6071 & 6.59137 \\
Leadership & 84 & 23.00 & 49.00 & 39.9286 & 7.29050 \\
Local Wisdom & 84 & 30.00 & 63.00 & 51.3810 & 8.55866 \\
Accountability & 84 & 27.00 & 70.00 & 55.5357 & 10.02821 \\
\hline
\end{tabular}

Source: Processed primary data, 2016

\subsection{Hypothesis Test and discussion}

The $\mathrm{R}$ square value of the regression model is used to know how large the variable's ability is free (independent) in describing the dependent variables. The magnitude of $\mathrm{R}$ square with a value of 0.716 , independent variables have a strong effect on the dependent variables. This means that $71.6 \%$ of the state Islamic religious college accountability can be explained by the variation of independent variables which is spirituality, organizational culture, leadership, and local wisdom. The remainder amounted to $28.4 \%$ (100\%$71.6 \%)$ or $0.53292 \times 100 \%=0.2839(28.40 \%)$ A variation of accountability of the state Islamic religious college cannot be explained by the four independent variables, but described by other variables outside of this research model.

Anova test (F Test) shows an $\mathrm{F}$ count value of 49.788 with a significance probability of 0.000 . The significant probability value of the test result of the $F$ is smaller than $\alpha=0.05(0.00<0.05)$. This suggests that jointly (simultaneously) the accountability of SIRC is influenced by spirituality, organizational culture, leadership, and local wisdom. Thus, test the individual parameters (t Test) can continue to answer the hypotheses that have been formulated before. Testing the significance of individual parameters $(t$ Test) or the influence of the four variables independent of the 
dependent variables with the level of alpa or significance

levels $(\alpha=5 \%)$ shown in the following table.

Table.3: Test Result Table

\begin{tabular}{|c|c|c|c|c|c|c|c|}
\hline \multirow{3}{*}{ Independent Variable } & \multicolumn{2}{|c|}{ Simultaneous Influence } & \multirow{3}{*}{$\begin{array}{c}\text { R-Square } \\
\left(\mathbf{R}^{2}\right)\end{array}$} & \multirow{3}{*}{$\begin{array}{c}\text { Residual } \\
\text { (E) }\end{array}$} & \multicolumn{3}{|c|}{ Individual Influence } \\
\hline & $\mathbf{F}$ & & & & Regression & $\mathbf{t}$ & \\
\hline & $\begin{array}{l}\text { Count } \\
\text { Table }\end{array}$ & Prob. (p) & & & $\begin{array}{c}\text { Coefficient } \\
\text { (р) }\end{array}$ & $\begin{array}{l}\text { Count } \\
\text { value }\end{array}$ & Prob. (p) \\
\hline$\overline{\text { Constant }}$ & \multirow{5}{*}{$\begin{array}{l}\infty \\
\infty \\
a \\
q\end{array}$} & \multirow{5}{*}{8} & \multirow{5}{*}{$\frac{0}{\pi}$} & \multirow{5}{*}{$\begin{array}{l}\text { ते } \\
\text { ñ. } \\
\text { ô }\end{array}$} & -4.442 & "-0,834 & 0,407 \\
\hline Spirituality & & & & & 0,384 & 2.162 & 0,034 \\
\hline Organization culture & & & & & 0,154 & 0,827 & 0,411 \\
\hline Leadership & & & & & 0,037 & 0,230 & 0,819 \\
\hline Local Wisdom & & & & & 0,705 & 4,532 & 0,000 \\
\hline
\end{tabular}

Dependent Variable: Accountability

Source: Processed primary data, 2016

Based on both tables of test results the above model can be presented the regression equation as follows:

$$
\begin{gathered}
Y=-4,442+0,384 x_{1}+0,154 x_{2}+0,037 x_{3}+0,705 x_{4}+ \\
0,5329
\end{gathered}
$$

Spirituality shows the calculated value of $t>t$ table value, which is $2.162>1.996$ with a significance probability of 0.034 . The significance probability 0.034 is under $\alpha=0.05$ $(0.035>0.05)$ with a coefficient of 0.384 . The results of this study show that spirituality has a significant positive effect on the accountability of the State Islamic Religious College in South Sulawesi $\left(\mathrm{H}_{1}\right.$ accepted). This indicates that accountability organizers, or stakeholders are always backed by a high level of spirituality. Without spirituality over high religious consciousness is not able to encourage the accountability of SIRC in South Sulawesi. SIRC in South Sulawesi is obliged to form the character of faith and piety for its academic, especially the stakeholders to maintain accountability in the management of their respective duties. The results of this study support the research of Milliman et al. (2003) That spirituality in the workplace is consistent with one's core beliefs and organizational values. The research of Randa (2011) finds a dimension of spiritual accountability in church organization, and spirituality is the primary dimension expressed in trust and love for God.
Elfianto's Research (2013) states that Islam sees the mandate as accountability, all of which are deposited to human beings as manadate Khalifatullah fil Ardh.

The variable description for spirituality shows a high mean value of 42.89 and is closer to the maximum value of 49.00. This means that the aspect of spirituality is a prioritized portion of the department's stakeholders to form accountability of SIRC in South Sulawesi Indonesia. The notion that working as a worship, increased faith and piety, soft skills (honesty, fairness, and hard work), religious values of university, and improvement of the welfare of academic civitas, especially the stakeholders became the determining factors of accountability on SIRC in South Sulawesi Indonesia. Thus, the university's leadership can use the element of spirituality as a consideration in determining the position of the stakeholders in the work units within the scope of SIRC in South Sulawesi Indonesia.

The organizational culture has a $\mathrm{t}$ count value $<\mathrm{t}$ table value, which is $0.827<1.996$ with a significance probability level of 0.411 . The significance probability 0.411 is above $\alpha=0.05(0.411>0.05)$. Thus, the results of the study showed that the organizational culture did not significantly affect the accountability of the State Islamic Religious College in South Sulawesi Indonesia $\left(\mathrm{H}_{2}\right.$ rejected). 
The organizational culture influence also shows a positive regression coefficient of 0.154 , meaning is the influence of a high organizational culture does not optimally accountability form in the SIRC's environment of South Sulawesi Indonesia. This condition indicates that the Islamic universities are unable to accommodate the religious symbols, values and norms of Islamic universities (organizations/Islamic institutions) in shaping the attitudes and behaviors of academic civitas to organize the accountability of SIRC in South Sulawesi Indonesia.

The standard deviation value for an organizational culture variable of 6.59 is the fourth largest standard deviation from the entire variable. However, the organizational culture variable has the mean (38.60) the lowest among the entire research variables. The indicative, that the organizational culture has a degree of the diversity of virginity that is also still ambiguous among respondents and tendency that the organizational culture is not important compared to spirituality and local wisdom in the implementation of SIRC's accountability in South Sulawesi Indonesia. Thus, the organizational culture does not (yet) become important to get priority as an element of the establishment of SIRC's accountability in South Sulawesi Indonesia.

The leadership has a $\mathrm{t}$ count value $<\mathrm{t}$ table value, which is $0.230<1.996$ with a significance probability level of 0.819 . The significance probability 0.819 is above $\alpha=$ $0.05(0.819>0.05)$. Thus, the results of the study showed that leadership did not significantly affect the accountability of the State Islamic Religious Colleges in South Sulawesi Indonesia $\left(\mathrm{H}_{3}\right.$ rejected). Although this hypothesis was rejected, the leadership influence showed a positive regression coefficient of 0.037 , meaning that high leadership would strive to enhance the implementation of SIRC's accountability in South Sulawesi Indonesia. This condition indicates that SIRC accommodates the suitability of Islamic universities's vision and mission, leadership capacity, leader responsibility, and leader interaction with academic civitas has not been maximally able to form the accountability of SIRC in South Sulawesi Indonesia.

The standard deviation value for leadership of 7.29 is the third largest standard deviation from the entire variable. Its indicative, leadership did not differ considerably from the organizational culture, which is the high diversity of the respondent's virginity to leadership variables. However, leadership has more power than the organizational culture, as its mean of 39.93 is greater than the organizational culture mean. Thus, the elements of Leadership not (yet) become important to get priority as an element of the forming of SIRC's accountability in South Sulawesi Indonesia.

Local wisdom has a $\mathrm{t}$ count value $>\mathrm{t}$ table value, which is $4.532>1.996$ with a significance probability level of 0.000 . The significance probability 0.000 is below $\alpha=$ $0.05(0.000<0.05)$ with a coefficient of 0.705 . The results of this research show that local wisdom has a significant positive influence on the accountability of the State Islamic Religious College. In South Sulawesi Indonesia $\left(\mathrm{H}_{4}\right.$ accepted). This indicates that the diversity of academic civitas background, upholding mutual respect (rights and responsibilities), the sense of kinship of academic civitas, and the application of local wisdom values in carry out the task of the stakeholder has a maximum contribution to form the accountability of SIRC in South Sulawesi Indonesia. Local wisdom values can form the academic civitas respecting the position and function of each within the organizational structure of Islamic colleges. The results of this study supported the research of Randa (2015) that local cultural values could be absorbed in the organization of the Catholic Church. Resecarch of Salle and Paranoan (2015) found that accountability was built on the values of local wisdom believed by local communities.

Variable descriptions for local wisdom show the highest mean value among independent variables, which is 51.38 and the highest standard of deviation of 8.56 is also among independent variables. This means that even though respondents have a high level of diversity in local wisdom, the statistical number (mean high value) shows that local wisdom is a priority scale for Islamic colleges in shaping SIRC's accountability in South Sulawesi Indonesia. The proximity of the mean value to the maximum value (63.00) compared to the minimum value (30.00) also indicates that local wisdom unregulated by Islamic colleges has always been reflected by the stakeholders of the working units in improving its accountability in carry out the trust that has been entrusted to it.

Thus, the aspect of spirituality and local wisdom lubricated the stakeholders, or the academic civitas that carried out additional duties as a structural officer to conduct SIRC's accountability in South Sulawesi Indonesia. It seems that both aspects of spirituality and local wisdom in the SIRC's environment are inseparable to form accountability, because the values of local wisdom are highly compatible with academic civitas spirituality, which is also reflected in daily life or activities to carry out the trust/duty in PTKIN 
South Sulawesi. The integration of spirituality with local wisdom is demonstrated by academic Civitas, among other who consider work to be one of worship to God, uphold mutual respect among academic civitas, and the importance of establishing brotherhood among academic civitas.

\section{CONCLUSION}

Spirituality has a significant positive effect on SIRC's accountability in South Sulawesi Indonesia. Spirituality involves efforts to discover one's destiny in life, developing a strong relationship between work related to work, and having consistency between one's core beliefs and organizational values, so that can improving organizational accountability. Local wisdom has a significant positive impact on SIRC's accountability in South Sulawesi Indonesia. Research explain that local values of South Sulawesi Indonesia, which are based on the concept of Sipakatau', Sipakainge', and Sipakalebbi' give meaning to the importance of accountability built in an organization as a whole to be accepted by all stakeholders.

The organizational culture has no significant effect on SIRC's accountability in South Sulawesi Indonesia. The high influence of organizational culture does not make a maximum of accountability in the SIRC's environment in South Sulawesi. This indicates that the Islamic colleges have not been able to accommodate the religious symbols, values and norms of SIRC in shaping the attitudes and behaviors of academic civitas. Leadership has no significant effect on SIRC's accountability in South Sulawesi. This condition indicates SIRC in accommodating the suitability of the vision and mission of Islamic college, leadership capacity, responsibility of leaders, and interaction of leaders with the academic civitas have not maximized to form the accountability of SIRC in South Sulawesi Indonesia.

The practice of SIRC's accountability in South Sulawesi has become a strengthening part of the formulation of concepts or accountability theory of the perspective of Islamic College entity. The accountability derived from spirituality and local wisdom becomes a key component of good university governance. Improving the quality of spirituality and behavior of local wisdom of South Sulawesi Indonesia in the individual to the position of the quality standards of SIRC governance in South Sulawesi. The rules that emphasize accountability will help to realize the sustainability of entity management (Islamic Universities and Religious Ministries).

\section{REFERENCES}

[1] Anzar, D.S. dan Y. Januarsari. 2011. Akuntabilitas dan Pengelolaan Keuangan di Masjid. (Sebuah Studi Kasus). Prosiding, Simposium Nasional Akuntansi XIV, Aceh.

[2] Arga, S.W. dan A. D. Mulawarman. 2014. Akuntabilitas Koperasi Syariah (Studi Kasus Pada Kanindo Syariah Jatim). Jurnal Ilmiah Mahasiswa, Fakultas Ekonomi dan Bisnis Universitas Brawijaya Malang.

[3] Campbell, C. and C. Rozsnyai. 2002. Quality Assurance and the Development of Bisnis Course Programmes. Paper on Higher Education. Bucharest, Europe.

[4] Effendi, S. 2003. Pengelolaan Perguruan Tinggi Menghadapi Tantangan Global. Makalah, Seminar Nasional Majelis Rektor Indonesia

[5] Efferin, S. 2015. Prospek Penelitian Kritis Akuntansi Berbasis Local Wisdom: Belajar dari Tri Hita Karana dan Udayana. Prosiding, Pertemuan Masyarakat Akuntansi Multiparadigma Nasional (MAMI), Universitas Udayana Denpasar Bali.

[6] Elfianto. 2013. Agency Theory dalam Perspektif Syariah. Makalah, Dosen Fakultas Ekonomi Universitas Tamansiswa Padang.

[7] Endahwati, Y.D. 2014. Akuntabilitas Pengelolaan Zakat, Infaq, dan Shadaqah (ZIS). Jurnal Ilmiah Akuntansi dan Humanika (JINAH), 4(1): 1356-1379.

[8] Fikri A, E. G. Sukoharsono, B. Purnomosidhi, dan I Triyuwono. 2010. Studi Fenomenologi Akuntabilitas Non Governmental Organization. Prosiding, Simposium Nasional Akuntansi XIII, Purwokerto.

[9] Gibson, J.L., J.M. Ivancevich, J.H. Donnely, and R. Konopaske. 2012. Organizations Behavior Stucture, Processes. Forteenth Edition. McGraw-Hill Companies Inc., New York.

[10] Gray, R. 2001. Thirty Years of Social Accounting, Reporting, and Auditing: what (if anything) have we learnt? Business Ethics: A European Review, 10(1): 9-15.

[11] Gray, R., J. Bebbington, and D. Collison. 2006. NGOs, Civil Society and Accountability: Making the People Accountable to Capital. Accounting, Auditing, and Accountability Journal, 19(3I): 319-348.

[12] Indriantoro, N. dan B. Supomo. 1999. Metodologi Penelitian Bisnis untuk Akuntansi dan Manajemen. Edisi Pertama. Badan Penerbit Fakultas Ekonomi, Yogyakarta.

[13] Kurniawan, M. 2013. Pengaruh Komitmen Organisasi, Budaya Organisasi, dan Kepuasan Kerja terhadap Kinerja Organisasi Publik (Studi Empiris pada SKPD Pemerintah Kabupaten Kerinci). Artikel Ilmiah, Fakultas Ekonomi-Universitas Negeri Padang.

[14] Mardiasmo. 2005. Akuntansi Sektor Publik. Penerbit Andi, Yogyakarta.

[15] Milliman, J., A.J. Czaplewski, and J. Ferguson. 2003. Workplace Spirituality and Employee Work Attitude. Journal of Organizational Change Management, 16 (4): 426-447. 
[16] Muawanah, U. 2010. Rating Corporate Governance dan Spiritual Islami di Perbankan Syariah: Pendekatan Mix Method. Disertasi, Universitas Brawijaya Malang.

[17] Mulawarman, A.D. 2007. Menggagas Neraca Syari'ah Berbasis Maal: Kontekstualisasi "Kekayaan Altruistik Islami”. Jurnal Akuntansi dan Keuangan Indonesia., 4(2): 169-192

[18] Ningsih, N.D., S.Musyarofah, dan A. R. Setiawan. 2015. Akuntabilitas Lillahita'ala Sebagai Puncak Akhir Pengelolaan Keuangan: Studi Fenomenologi pada Yayasan Masjid AlFalah Surabaya. Prosiding, Konferensi Regional Akuntansi (KRA) II, Malang

[19] Nugroho, I. 2013. Mengembangkan Moral dan Akuntabilitas Kepemimpinan Nasional (Deskripsi Indeks Kepemimpinan Nasional Indonesia, IKNI). Enam Windu Lehmanas RI: Merajut Nusantara: 205-245.

[20] Nurhayati, I. 2014. Pengaruh Otonomi dan Akuntabilitas Perguruan Tinggi terhadap Kinerja Manajerial. Trikonomika, 13(1): 1-12.

[21] Pusparini, N. 2010. Dimensi Kepemimpinan Aparatur dalam Perspektif Pelayanan Publik. Jurnal Sosial dan Politik, X(2): 1-17.

[22] Rafaeli, A. and M. Worline. 1999. Symbol in Organization culture. Handbook of Organization Culture and Climate.

[23] Ramatni, A. 2013. Akuntabilitas Manajemen Kinerja Satuan Pendidikan Kecakapan Hidup Berbasis Budaya Lokal. Jurnal Penelitian Universitas Jambi Seri Humaniora, 5(1).

[24] Randa, F. 2011. Rekonstruksi Konsep Akuntabilitas Organisasi Gereja: (Studi Etnografi Kritis Inkulturatif pada Gereja Katolik di Tana Toraja). Prosiding, Simposium Nasional Akuntansi XIV, Aceh.

[25] Randa, F. 2013. Memahami Dimensi Akuntabilitas pada Organisasi Pemerintah Daerah (Studi Etnografi pada Pemerintah Kabupaten Tanah Toraja). Prosiding, Simposium Nasional Akuntansi XVI, Manado.

[26] Randa, F. 2015. Akuntabilitas Organisasi dengan Spirit Siri'na Pacce dan Misa Kada Dipotuo Pantang Kada Dipomate. Akuntansi Makassaran. Seri Akuntansi Multiparadigma Indonesia, . 1(2): 77-80

[27] Roberts, J. and R. Scapens. 1985. Accounting Systems and Systems of Accountability Understanding Accounting Practices In Their Organisational context. Accounting, Organisations and Society, 10(4): 443-356.

[28] Saerang, D.P.E. (2003) Accountability and Accounting in a Religious Organization: An Interpretive Ethnographic Study The Pentacostal Church of Indonesia. Dissertation. Walonggong University.

[29] Sadjarto, A. 2000. Akuntabilitas dan Pengukuran Kinerja Pemerintahan. Jurnal Akuntansi dan Keuangan, 2(2): 138-150

[30] Salle, I.Z dan N. Paranoan. 2015. Akuntabilitas Manuntungi. Akuntansi Makassaran. Seri Akuntansi Multiparadigma Indonesia, . 1(2): 150-159.

[31] Sartini. 2004. Menggali Kearifan Lokal Nusantara Sebuah Kajian Filsafati. Jurnal Filsafat, 37(37): 111-120.
[32] Shahzad, F., R.A. Luqman, A.R. Khan, and L. Shabir. 2012. Impact of Organizational Culture on Organizational Performance: An Overview. Interdiciplinary Journal Culture on Organizational Research Business, 3(9): 975-985.

[33] Sutjiati, R. 2008. Studi Akuntabilitas pada Perguruan Tinggi Swasta: Suatu Kajian Ilmu Administrasi Pendidikan. Disertasi, Universitas Pendidikan Indonesia, Bandung.

[34] Triyono. 2012. Budaya Organisasi (Studi Eksplorasi Pada Universitas Muhammadiyah Semarang). Jurnal Value Added, 9(1): $1-20$.

[35] Triyuwono, I. 2006. Perspektif, Metodologi, dan Teori Akuntansi Syariah. PT Raja Grafindo Persada, Jakarta.

[36] Triyuwono, I. 2011. Mengangkat 'Sing Liyan' untuk formulasi nilai tambah syariah. Jurnal Akuntansi Multiparadigma, 2(2): 186-368.

[37] Wikipedia. 2015. Sistem Akuntabilitas Kinerja Instansi Pemerintah Tahun 2000, Lembaga Administrasi Negara. www.academia.edu, diakses 28 Maret. 